\title{
School meals in Catalonia: surveillance and quality control
}

\author{
M Asunción Roset ${ }^{1, *}$ and Blanca Gonzalvo ${ }^{2}$ \\ 'Director/Manager School Health Education Programme, Education Department, Generalitat de Catalunya, \\ Via Augusta 202-226, E-08021 Barcelona, Spain: ${ }^{2}$ Parc Científic de Barcelona, GRNC - Grup Recerca Nutrició \\ Comunitària (Community Nutrition Research Group), University of Barcelona, Barcelona, Spain
}

\begin{abstract}
The Education Council of the Catalonian government drew up a programme to improve the quality control of school canteens in Catalonia. The objectives of this programme were to contribute to developing healthier eating habits in school children through school canteens and to improve school canteen services considering other aspects such as service, operation, management, end-users, frontline staff and supervisors of menu planning.

This paper deals with two programme components aiming at introducing Nutrition in the school syllabus and school menu assessment. Various departments, organisations and associations were involved in programme development and implementation.

Initial analysis was based on information collected from formal administrative reports completed by a survey on 100 primary schools. From this preliminary analysis it was concluded that problem identification needs to be completed by an understanding of underlying reasons in order to design adequate solutions and guarantee implementation.
\end{abstract}

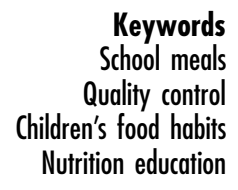

Nutrition education to encourage healthy eating habits in children is more than providing knowledge on balanced nutrition. Nutrition education considers all actions aimed at modifying knowledge, attitudes and food behaviour in individuals, groups and communities ${ }^{1}$. In order to improve health and quality of life through good nutrition, health and nutrition policies should be planned on the basis of identified problems ${ }^{2}$.

Catalonia is one of the Autonomous Regions in Spain, located in the north east of the country, on the Mediterranean coast. The Regional Government is responsible for developing regulations for education and health. During the 1980s the Departments of Education and Health in the Regional Government of Catalonia pioneered in Spain a joint Health Education Programme for Primary Schools, leaded by Dr Lluis Salleras, head of the Department of Public Health at that time. Nutrition was one of the areas considered in the school curriculum as a cross-sectional subject ${ }^{3}$.

Other areas have gained importance in later years due to social changes: what children have learned in the classroom can be practised in the canteen, including hygiene, nutrition, sensorial awareness and meal service $^{4}$. Family participation in the process is crucial, since they should provide adequate nutritious food at home and contribute to the development of the child's food habits.
The New Education Planning Reform (LOGSE) started in 1990 introduced important changes in the school organisation system, i.e. secondary school starts at the age of 12 years compared with 14 years so far $^{5}$, and thus secondary schools should provide the opportunity to have school meals. Additionally, health education and nutrition education can be developed as cross-sectional subjects in every primary and secondary school.

The educational role of school canteens has not always been recognised. In the beginning they had mainly a welfare role. In 1935 school canteens were defined as 'instruments to encourage feelings of humanity, fraternity, help and gratitude in children'. It was in later years that the educational role was acknowledged, taking advantage of the associated free time to share this task with the family ${ }^{6}$.

School canteens are nowadays considered community dining halls regulated by public health authorities and must comply to subsequent norms regarding food safety ${ }^{7}$. From the educational perspective, the Right to Education Act 1985 (LODE) drafted a legal framework under the School Board - Foresaw (art. 42.g), drawing up guidelines for planning complementary activities, visits, trips, canteens and summer camps. The Ministry of Education and Science and several of the Autonomous Communities (administrative regions) have been progressively regulating aspects referring to school canteen 
services $^{8}$. The Department of Education of Catalonia took a definitive step forward in 1996 with the publication of Decree 160/96, May 14th regulating already existing services in local state schools and fostered a working group to analyse the situation of school canteen services and draw up proposals to improve them.

The private sector, particularly mass catering companies, also plays an important role (the first decrees regulating collective dining halls appeared in Europe around 1970). Increasing demand for mass catering services (hospitals, businesses, schools, etc.) during the 1980s generated higher quality standards in all respects: dietary guidelines, adequate technology for product processing and a higher level of professional preparation?

\section{Catalonian global programme to improve school canteens}

The Department of Education of Catalonia drew up a Global Improvement Programme for School Canteens to analyse, plan and improve the quality of school canteens.

Initial situation analysis was based on a follow-up survey of safety conditions of Catalonian school canteens (Health Department in collaboration with the Education Department) and administrative reports on school canteens assessing nutritional aspects. The information was completed by a cross-sectional survey to assess the situation of school canteens in a sample of 100 primary schools. The information was collected from the heads of the canteen service, carers, kitchen staff and pupils aged $6-14$ years $^{10}$. Underlying causes of the problems identified and possible solutions were considered.

Goals selected for the programme were the following: to guarantee quality standards by monitoring suppliers and food quality; to improve user confidence; to ensure professional response of frontline staff by means of a clear job definition and consequent consolidation of a professional profile; to establish rigorous menu planning by means of guidelines and qualified advisers, thus ensuring the nutritional quality of the menu; to draw up school regulations for improvement that, together with official regulations such as the Collective Dining-hall Decree, would provide an overall legal framework for internal management; to foster geographic decentralisation of management through local councils, to bring the management closer to the public and to ensure efficient management through public tenders to control expenses.

Actions were carried out in co-ordination with various programmes and departments of the Catalonian government: the Food and Nutrition Programme of the Public Health Department, the School Health Education Programme, the General Secretary for Youth and the regional offices of the Boards of Health and Education.

Contributions from the Rural District Councils, parents' associations, the school centres themselves and the caterers' association were also considered.

\section{Programme components}

\section{Nutrition education}

Focused on promoting and/or improving eating habits of school canteen users ${ }^{11}$, the overall objective for this component was to increase the presence of nutrition education programmes within school canteens. The specific objectives to achieve this were the following.

- Students - to increase their knowledge about food (both nutritional and cultural aspects); to improve students' eating habits (e.g. increase the number of students who have breakfast at home, reduce the consumption of sweets); to improve students' hygiene practices related to food and eating (e.g. improve dental hygiene habits).

- Monitors - to increase training in nutrition, educational-psychological aspects and organisation.

- Kitchen staff - to inform them on personal hygiene and food handling; to make frontline staff in direct contact with students and those who prepare the food leaders in quality.

- Director/Head of Service - to improve quality control; to improve co-ordination with families; to integrate canteen activities in the centre's educational project.

Resources allocated to achieve these goals consisted of teaching support materials for workshop and educational activities; training programmes for professionals; and communication links with families.

Reinforcement procedures considered included the following.

- Nutrition education projects in agreement with the criteria of the European Network of Health Promoting Schools (in 18 of the 22 Catalonian schools in the network).

- Monitoring of school food projects in co-ordination with the Health Education Programme and in collaboration with organisations and/or foundations (the General Council of Colleges of Pharmacists, the College of Doctorates and Graduates of Catalonia).

- Introduction of aspects related to school canteen services in the health and food subjects of the teachers' training programme.

- Collaboration in activities organised by parents' associations.

\section{Menu assessment}

Menus offered in school canteens should provide variety, balance and user satisfaction. This means they must comply with safety, health and dietetic quality criteria as well as student acceptance ${ }^{12-17}$. 
The general objective for this component was the majority of school canteens will reach the required level of information, distribution and compliance with the prerequisites of a balanced diet by 2002'.

Specific objectives to achieve this goal were the following.

- Menus will have a standardised description of main dishes, side dishes, dessert, presentation of dishes and improved menu rotation.

- To unify responsibilities in the design and to strengthen the presence of specialised personnel.

Resources allocated to achieve these objectives consisted of supportive materials (menu guides) and teaching materials for workshops with students. The Department of Education in collaboration with the Departments of Health and Social Security according to Decree 160/96 established a unit for menu assessment and supervision, and to reply to enquiries from schools, parents' associations, local councils or companies depending on the type of school management. A procedure was started to improve participation of frontline staff and kitchen personnel together with monitoring students' likes and dislikes regarding the menus.

\section{Conclusions}

- Nutrition education can be introduced in schools through canteens.

- The menu guidance programme contributes to ensure the provision of a healthy, balanced diet at school, to advise the family how to complement their children's daily diet and to collaborate in the promotion of healthy eating habits.

- In order to improve quality of the service, activities should be carried out in a systematic and integral way. Human resources involved deserve special consideration.

- Adequate resources should be allocated to ensure implementation of canteen improvement programmes and desirably it should be introduced as part of school activity.

\section{References}

1 Aranceta J. Nutrición en la edad evolutiva. In: Serra Ll, Aranceta J, Mataix J, eds. Nutrición y Salud Pública. Barcelona: Masson, 1995; 185-92.

2 Generalitat de Catalunya. Libre Blanc: Evaluació de l'Estat Nutricional de la Població Catalana. Barcelona: Departament de Sanitat i Seguretat Social, 1996.

3 Programa d'Educació per a la Salut a l'Escola. Alimentació $i$ Nutrició. Barcelona: Departament d'Ensenyament, 1994.

4 Aranceta J. El comedor escolar: salud docencia y servicio. Caternews 1993; 7: 19-42.

5 Generalitat de Catalunya. Curriculum de Secundaria. Barcelona: Departament d'Ensenyament, 1994.

6 Domingo A. La educación para la Salud en el comedor escolar, Barcelona. Aula 1994; 32: 54-8.

7 Direcció General de Salut Pública. Inspecció $i$ Control Sanitari dels Establiments de Restauració. Barcelona: Departament de Sanitat i Seguretat Social, 1995.

8 Generalitat de Catalunya. Legislació d'Ensenyament a Catalunya. Barcelona: Departament d'Ensenyament, 1995.

9 García Jalón MI. Sistema de análisis y control de riesgos identificación y puntos críticos en restauración colectiva. In: Serra Ll, Aranceta J, Mataix J, eds. Nutrición y Salud Pública. Barcelona: Masson, 1995; 365-74.

10 Roset MA. Una Aproximació a la Organització $i$ Hàbits Alimentaris en els Menjadors Escolars de Catalunya. Barcelona: Universitat de Barcelona, 1998.

11 Direcció General de Salut Pública. Normas per Manipular Correctament els Aliments. Barcelona: Departament de Sanitat i Seguretat Social, 1994.

12 Beni C, Quer J, Roset MA, Salvador G. Planificación de menús en el comedor escolar. Aula 1994; 32: 59-62.

13 Roset A, Salvador G. Orientaciones para la planificación de menús en el comedor escolar: a review. Actividad Dietética 2000; 10: 24-8.

14 Dixey R, Heindl I, Loureiro I, Pérez-Rodrigo C, Snel J, Warnking P. Healthy Eating for Young People in Europe. Nutrition Education in Health Promoting Schools. Copenhagen: WHO-European Network of Health Promoting Schools, 1999.

15 Pérez-Rodrigo C, Klepp KI, Yngve A, Sjöström M, Stockley L, Aranceta J. The school setting: an opportunity for the implementation of Dietary Guidelines. Public Health Nutr. 2001; 4: 717-24.

16 Collins Pateman B, McKinney P, Kann P, Leavy Small M, Warren W, Collins JL. School food service. J. Sch. Health 1995; 65: 327-32.

17 Meyer MK. Top predictors of middle/junior high school student's satisfaction with school foodservice and nutrition programs. J. Am. Diet. Assoc. 2000; 100: 100-3. 